\title{
EUROPEAN FUNDING - IMPACT ON RESEARCH CAPACITY IN CROATIA
}

\author{
Vesna Kotarski \\ Centre for Research, Development and Technology Transfer \\ University of Zagreb, Croatia \\ vesna.kotarski@unizg.hr \\ Article info \\ Paper category: Preliminary paper \\ Received: 4. 11. 2015 . \\ Accepted: 15. 9. 2016. \\ JEL classification: $\mathrm{O}_{2}$
}




\begin{abstract}
Limited national budgetary resources for $R \& D$ in period from 2007 to 2013 imposed a need for Croatian researchers to apply for European research grants. A challenge for effective absorption of European Structural and Investment Funds in the period 2014 to 2020, highlight a need to assess the impact of this external funding on research capacity in Croatia in 2007-2013 period. Qualitative interviews with grant recipients from Ruder Boskovic Institute revealed intangible achievements in terms of research career, enhanced interaction and knowledge transfer to business community, improved research management competences and possibilities for collaboration with internationally recognized research teams. Similar results from studies carried out in other countries indicates the importance of intangible achievements of research grants, which are becoming more and more relevant in the context of public policies (networking, cooperation, strategic planning, knowledge management). The use of EU funds is an extremely complex process which requires a change of approach to the use of public funds and the introduction of the principle of transparency of procedures for all stakeholders in the process, equal access to information and sound financial management. Weaknesses of the Croatian scientific system and absence of will to support excellent research through competitive funding present real threats to successful participation of Croatian researchers in the European framework programs and other external research funding programs. Findings of the study provide valuable insight for national authorities in terms of effective management of national research and innovation programs while maximizing the potential impact of EUfunds allocated.
\end{abstract}

\title{
Keywords:
}

research and development; research management; grants; intangible assets; innovation 


\section{INTRODUCTION}

In terms of limited national budgetary resources for research and development, the possibility of using financial resources from EU funds and programs for less developed EU countries such as Croatia, are of particular importance. In other $\mathrm{EU}$ countries at similar income level, the share of EU funding devoted to research, development and innovation, represents about $160 \%$ of the national public R\&D budget (GBAORD) in Latvia and Lithuania, about $120 \%$ in Estonia, Poland and Slovak Republic, and 60-80\% in Bulgaria, Czech Republic, Hungary and Slovenia. During the period 2007-2013 a substantial amount of public funding for research in Croatia has come from international sources: World Bank and the European Union. In 2007-2013 the share of direct funding from the European Commission was roughly equal to funding from national sources. Looking at Eurostat's statistics on research and development Croatia has low gross expenditure on R\&D as \% of GDP (o,81 in 2013) compared to $\mathrm{EU}_{2} 8$ (2,01 in 2013). Current unstable government budget with low priority given to research, and challenge for effective absorption of European Structural and Investment Funds in the period 2014, to 2020, highlight a need to assess the impact of this external funding on research capacity of Croatian universities and research institutions in $2007^{-2013}$ period.

A number of studies have analyzed the impact of research grants on research performance in terms of scientific production and education (Auranen and Nieminen 2010; Liefner 2003; Geuna and Martin 2003; Larsen 2011), but mostly in Western European countries like Denmark (Bloch et al. 2014) and Sweden (Melin and Danell 2006). Latvian government carried out the ex-post evaluation of results and impact of EU funded investments in the field of education and science in previous programming periods (after EU accession in 2004) and the major conclusion has been drawn that EU Structural Funds support was vitally important. Research conducted for the Western Balkans and Croatian is mainly focused on the analysis of the cause of a modest number of institutions that have managed to include themselves in the EU programs for research and development and difficulties in the process of inclusion and implementation of projects financed from international sources (Rivera Leon et al. 2010). In paper published by Matković and Radocaj Novak, the authors analyzed the participation of Croatian organizations in the Seventh Framework Programme in terms of specific programs, funding schemes and the coordinator organizations (Matković and Radocaj Novak, 2013). The findings of the study point to moderate success of Croatia's participation and provide policy recommendations to national authorities in order to increase the participation in future EU programs for science and innovation.

The research objective of this paper is to analyses the gaps in national science policy for effective research management in terms of $\mathrm{EU}$ funding opportunities. The research methods used are literature review and qualitative interviews with grant 
recipients from Ruder Boskovic Institute regarding their experiences in using EU funds for research and development. This paper is structured as follows: in section II, overview of Croatian research funding system and evidence from participation in EU programs funding science and innovation. Section III discusses the benefits and constraints of EU funding policies while section IV analyses the concept of Smart Specialization Strategy as a strategic approach to economic development through targeted support to research and innovation. In the last section concluded remarks are presented.

\section{THE IMPACT OF EU FUNDING ON COUNTRY'S RESEARCH POTENTIAL}

The main principle of funding research at EU level is to support excellent research through competitive funding or competitive research grants. The structure of funding both at European and national levels increasingly gravitates towards projectbased funding (Herlitschka et al. 2008). R\&D funding schemes aiming at enhancing conditions for research and improving research output are major instruments in public research policy. A key reason for allocating part of national research funding through competitive grants is to target the most promising research projects and support the best researchers. The underlying idea is that competitive grant schemes can increase research performance and optimize funding impact (Langfeldt et al. 2015).

In this context should the scientific system in Croatia be considered. It is currently in the process of defining key reform elements that should structure Croatian science on the same principles on which it is built in scientifically advanced countries. Development plans and scientific and technological policy measures defined by the Croatian Government should result in the transfer of research results in new goods, services and processes, but also have a key role in defining the response to the challenges of social development, culture and environmental concerns. Achieving competitiveness on European and global markets implies economic growth based on knowledge, education and innovation, that is, the transition towards knowledge economy. Driving force of the knowledge economy is the capitalization of knowledge realized through innovation, thus integrating scientific research, its technological and commercial exploitation.

In Croatia, science is for the most part financed by public funds from the state budget. It is mostly used for salaries, material costs and, up until October 2013, for basic research projects (so called zProjects). This system of financing, rigid and conservative (Hasan et al., 2008), is based on the mechanism of "historical allocation" and does not provide medium and long-term planning, or the determination of strategic goals (Doolan et al., 2012). According to Eurostat's data on investment in research and development of the EU member states for the period 2003-2013, 
expressed by GERD (Gross domestic expenditure on R\% D - \% of GDP), Croatian allocations for R \& D in 2013 make $0.81 \%$ of GDP, while the average of EU-28 countries in the same year was 2.01\% (Eurostat, 2015). In addition to worrying low share of investment in research and development, the more worrying is the structure of public spending where approximately $90 \%$ of the total amount is spent on salaries of employees in the research and development sector. The question that arises is: how much remains for research and development projects, and whether the limited resources are allocated by clear and transparent criteria of excellence through competitive tenders?

As the base for the possible answer the following fact should be brought up: in the period of 2007-2013 the Ministry of Science, Education and Sport financed 2,314 research projects carried out by 5,622 scientists employed in public research institutes and universities: 2.4,3 scientists per project! During 2010, the number of projects was reduced to 2,089 projects in 2012 there were 1,919 projects, but it is still far from establishing a system of integrated research projects which would be able to establish a critical mass of internationally significant research groups. De facto the success rate was almost 100\%, and anyone that submitted their project received funding for research. Although these funds are very modest in terms of capacity to carry out internationally relevant research, still, for the national criteria they are continued to be acceptable. The problem is that such system of financing does not stimulate concentration of scientific research around the national strategic priorities, which would lead to significant scientific results. This makes the responsibilities of the institutes and universities for quality assurance and final social and economic potential of the relevant outcomes of scientific research more important. A unique approach that will link thematically related and complementary research and researchers, thus consolidate and strengthen their research and innovation potential, is the only way towards more relevant and internationally recognized research.

Therefore, in 2011 initiated a process to amend the existing Law on the Croatian Science Foundation with the goal of the Foundation to take a central role in the competitive funding system. The Foundation was established as an independent financing system formed like other research councils in the world. Since 2001 Foundation has developed the organizational and human capacities for the implementation of European standards in the evaluation, monitoring and financing of research projects and researchers. With the Foundation, one of the national competitive funding program for research was the Fund "Unity Through Knowledge" (UKF) set up in 2007 within the framework of Science and Technology Project funded by the World Bank, and ending 31.05.2011. By taking a central part in financing research projects in Croatia, the Foundation published in 2014 the first calls for proposals. So we can say that the system of competitive funding of research projects was established with a total annual budget of 6.75 million euros. More than half of the total amount is allocated for employment of doctoral students. 
This brings us to the conclusion that, in the period from 2007 - 2013, significant funds for financing scientific research, development and technology projects were available only through external research funding programs. Most of it under the Seventh Framework Programme for Research and Technological Development of the European Union $\left(\mathrm{FP}_{7}\right)$ and in small extent, under the Instrument for Pre-Accession Assistance (IPA) component IIIC Fund for Science and Innovation (Science and Innovation Fund - SIIF). Although Croatian scientists participated in European Framework Programs for Research and Development since 2006, the participation rate is not satisfactory and only relates to a very small number of research groups. The evidence from the participation of South East European / Western Balkan Countries (SEE/WBC) in European level programs funding science and innovation clearly point to progress over the last five years. However, the difficulty for the countries of the Western Balkans to compete in international level programs where excellence is the driving criteria is clearly visible (Rivera Leon et al. 2010).

During the period from 2007 to 2013 a substantial amount of public funding for research in Croatia had come from international sources: World Bank and the European Union. In 2007-2013 the share of direct funding from the European Commission was roughly equal to funding from national sources. Competitive funds and funders play an important role, since the provided funding is always linked to specific conditions and requirements with respect to the type of activities they support as well as in legal and financial terms. Consequently, these funding conditions and requirements developed significant influence and are closely interconnected with universities' management approaches in general and financial management in particular. „External" funding of research is very important for ensuring excellence both in research and in research management, in areas of strategic development which are essential if universities and research institutions are to remain sustainable and competitive (Herlitschka et al. 2008). A number of studies have examined the use of performance-based funding in allocating public funding across departments and universities, and its impact on education and scientific production (Auranen and Nieminen 2010; Liefner 2003; Geuna and Martin 2003; Larsen 2011). The overall rationale for an increased reliance on competitive funding is that competitive financing mechanisms will funnel resources to those researchers and universities that are most qualified, with subsequent improvements in performance within both research and education. The results of the study carried out in Denmark indicate that while research grants have a positive impact on the research performed under the grant itself, there are very important secondary effects on research performance through positive effects on academic career advancement (Bloch et al. 2014). Qualitative interviews with grant recipients from Ruder Boskovic Institute provided insight into how grants impact their research careers, through improved academic skills and status, enhancing interaction and knowledge transfer to business community, improving research management competencies and improving chances for academic ad- 
vancement, collaboration and other academic activities. Another study - comparing funded and rejected applicants for large 6-years grants to young researchers in Sweden - found no impact on the number of publications. Positive effects for the grant recipients were found in terms of a higher proportion of international co-authorship, as well as securing further funding for their research groups (Melin and Danell 2006). In 2011 Latvian government carried out the ex-post evaluation of results and impact of EU funded investments in the field of education and science in previous programming periods (after EU accession in 2004) and the major conclusion has been drawn that EU Structural Funds support was vitally important. National funding of education and research sector's development was moderated comparing it with EU investments. Thus, those investments stimulated the sector to develop in difficult economical years. 4,0\% of overall allocation for higher education was invested in research potential growth i.e. grants for doctoral studies and postdoctoral research. Doctoral study support has had a positive effect - total number of research personnel in Latvia has grown by $29 \%$ from 2004 , to 2009.

\section{THE BENEFITS / CONSTRAINTS OF EU FUNDING POLICIES}

The financial resources available through the European funds, for the less developed countries with limited national budgets particularly in the sector of research and development, opens the possibility of significant financial contributions to the already modest R\&D budgets. This is an opportunity for integration into the European Research Area by participating in research projects and programs, and acquaintance with the process of decision-making on research policy at European level (Rivera Leon et al. 2010). The use of EU funds is an extremely complex process which requires a change of approach to the use of public funds and the introduction of the principle of transparency of procedures for all stakeholders in the process, equal access to information and sound financial management of EU funds. Although the biggest political responsibility for ensuring the implementation of these principles is on European Commission, a great responsibility is on national authorities as well, because almost $80 \%$ of EU funds are managed at the national level (shared management). The rest of the funds are managed by the European Commission through its departments ("Directorates-General") and the executive agencies (direct management). Funds are used to implement policies and strategies which affect the quality of life of all European citizens (innovation, cohesion, agricultural, economic, monetary, foreign, security, environmental protection, education and other policies). By these policies European Union complements and adds value to activities carried out by national governments, through EU funds which are instruments for the implementation of these policies. A necessary prerequisite for the use of EU funds is the existence of strategic development plans with identified thematic objectives and investments priorities, instruments for their implementation and measurable result indicators. 
The Europe 2020 strategy is a strategy of growth in Europe in the period from 2010 th to 2020th with which Europe is to respond to globalization and the economic crisis bringing back competitiveness to the European economy. Among the five areas of growth that Europe has recognized as the key to the further development are innovation, employment, climate / energy, education and social inclusion. Promoting innovation is an integral part of the concept of smart, sustainable and inclusive growth that Europe plans to achieve in the next 7 years. The instruments to achieve these objectives are defined through seven flagship initiatives of the Europe 2020 strategy: Innovation Union, Digital Agenda for Europe, Youth on the Move, Resourceefficient Europe, An industrial policy for the globalization era, Agenda for new skills and jobs and the European platform against poverty. Innovation Union aims to build a robust system of research and innovation synergy of all stakeholders. Europe wants to change a long-standing trend of lagging behind the US and Japan economies, by increasing investment in research and development as well as creating a more efficient model for the commercialization of scientific research results. Although Europe leads in the number of scientific publications in the world, it continues to lag behind in the application of research results. System of supporting innovation, in the context of legislation, financing and education, is still not sufficiently developed, in order to result in more efficient transfer of ideas to the market (http://ec.europa.eu/ europe2020/index_en.htm).

Unlike Europe, which has identified its strategic priorities and investment areas for future development and consolidate all into one comprehensive document: Europe 2020, in Croatia we have 14, sectoral and horizontal strategies, but there is no national strategy for development. So, the question arises: based on which national priorities and analysis were these sectoral strategies adopted? Was it only just for commitments we have taken on accession to the EU, and a necessary condition for the use of EU funds? How else to explain the situation but vividly, exactly how Mrs. Tania Friederichs did, the coordinator of the European Commission for Croatia in the field of research and development: "We are talking about the smart specialization, that is, the analysis of the national economy and goal-setting, in which to invest, so that Croatia could most efficiently and sustainably growth in the future, and from the Croatian government, we got amazing information that you if would like to focus on as many as 13 industries and more, and you are still asking whether such a large list could be extended to another two to three industries ".

In view of the above issues, the question is: What can be expected from the $\mathrm{Na}$ tional Innovation Strategy 2013-2020 in whose preparation work began following the signing ceremony of the memorandum on cooperation between the Ministry of Economy and the Ministry of Science, Education and Sports in May 2012, and that is still pending? Explanation of the purpose of adopting this strategy is very significant: defining the institutional framework and innovation policies regarding the optimal absorption of EU funds, so that Croatia could withdraw funds from the EU programs allocated for 
science and innovation! From this explanation and the fact that most national strategies are based on priorities set out by the Europe which are relevant to the developed EU countries, and that it is not possible to find data on the financial framework of the implementation of these strategies (allocated budgetary resources), it can be concluded that strategies are a wish list of which will some perhaps be partly achieved mainly with the help of EU funds. In the operational program Competitiveness and Cohesion 2014-2020 that serves as a basis for the use of EU funds in that period, research and development sector can count on the part of the funds allocated to increase the competitiveness of the economy (1 billion EUR) and EUR 600 million from other segments of the operational program. To further strengthen the scientific excellence and support the processes of commercialization of research results, it is especially important to participate in EU framework programs for research and innovation. The participation of Croatian researchers in $\mathrm{FP}_{7}$, as measured by the total amount of national contribution paid into the EU budget and actual financial contribution to the total contracted $\mathrm{FP}_{7}$ projects, can be regarded as positive (Matković, 2013). However, the results could have been much better. Analysis of the results and plans for improvements of participation in the new Framework Programme started in 2013, in the last year of the $\mathrm{FP}_{7}$ program. The same year an Action Plan to raise the absorption capacity of the Croatian participation in the Framework Programmes for period 2013-2015 was adopted. The plan contains: measures that include all essential aspects of the implementation of the Framework Programme in the reality of Croatian scientific community, measures to improve administrative support and actions in terms of support to scientists in preparation and implementation of their projects, measures to reward successful applications and applicants in terms of additional funding and career advancement. Analysis of research and innovation infrastructure and identified priorities for future investment is one of the preconditions for participation in EU programs. Therefore, in 2014, a document called Croatian Research and Innovation Infrastructures Roadmap was drafted. Ministry of Science, Education and Sport, presented it as: „... foundation for future investment in national and international (infrastructure) projects, taking into account the feasible financial framework. The Roadmap is a living document which means it will be continuously updated. This document represents the first national Research and Innovation Infrastructures Roadmap with the purpose to identify research potential in Croatia in order to direct further development of research infrastructures. At the same time, the Roadmap should ensure support for the implementation of measures stated in the Strategy for Education, Science and Technology, the National Innovation Strategy and Smart Specialization Strategy. "

During the development of the Roadmap, a SWOT analysis was made, which showed the following weaknesses of the Croatian scientific system, relevant to the participation in European programs for research and development:

- Unclear rules and the legal framework for the project management of the Framework Research Programme. 
- Possibility of career advancement, even to the highest scientific titles, without any recognizable international research carried out.

- Lack of motivation and effort to apply for international research grants, especially projects of scientific excellence of the European Research Council (ERC).

- Insufficient incoming and outgoing mobility of scientists, including insufficient number of Marie Curie projects, which results in modest participation in international scientific collaboration, programs and projects.

- A particular problem occurred with the projects requiring an open recruitment and employment of foreigners, and portability of grants (from foreign to national institution) where existing legislation proved to be extremely rigid, like Croatian citizenship as a condition to enter into Register of Scientists, special agreements for health and pension insurance and similar obstacles (Croatian Research and Innovation Infrastructures Roadmap, 2014).

These are the real threats to successful participation of Croatian researchers in the future framework programs:

- Retention of the existing situation in the system of promotion to higher scientific title, or non-inclusion of criteria of success in international competitive projects in the election to higher scientific titles would weaken the motivation of Croatian scientists and reduce the Croatian participation in international programs.

- Absence of a national awarding the best applicants on international competitive tenders, especially in projects of excellence of the ERC, will discourage excellent researchers and consequently force them to leave the country ("brain drain").

- Unclear rules of implementation and administrative management of international projects will allow different interpretations of the same issues by different research organizations and weaken the motivation of high-quality individuals to participate or coordinate international projects.

With all the obstacles that must be overcome at the national level, there is another element relevant for the entire EU, with an increasingly negative impact on the motivation for participation in European programs and funds. It is a problem of low success rates in the EU research funding programs, which began to seriously concern the European Commission. To quote Robert-Jan Smiths, European Commission's Director-General for Research and Innovation: "The EU's research program Horizon 2020 is more popular than ever before. But with our success rates we're heading to a situation where we have to be very careful not to scare away top researchers. In the UK, success rate is around 3०\% when applying to the major research councils. In the US, success rate is between $22 \%$ and $24 \%$ for the National Science Foundation and $18 \%$ to $21 \%$ for the National Institutes of Health. In Australia where public R\&D funding has been cut, applicants to the National Health and Medical Research 
Council have a $21 \%$ chance of success. Under $\mathrm{FP}_{7}$ success rate was from $19 \%$ to $21 \%$ and now in $\mathrm{H}_{2} \mathrm{O} 2 \mathrm{O}$ has dropped down from $12 \%$ to $14 \%$. The success rate of Southeast European countries in $\mathrm{FP}_{7}$ is highly variable year-on-year (2007-2010), which, probably, reflects specific calls targeted at SEE / WBC countries. The analysis of success rates and the patterns of success rates with specific partner countries tend to point to the WBC succeeding more and more in calls specifically aimed at their needs and potential. Moreover, the average success rate of $17 \%$ is still significantly below the $\mathrm{EU}_{27}$ average $(21 \%)$ and that of the Baltic countries $(22 \%)$ as a benchmark for the EU 27 countries with a similar scale amongst the EU27 (Rivera Leon et al. 2010).

In addition to poor success rate, a large number of European researchers critically refers to some other elements of the Framework Programme which are becoming a decisive factor in obtaining the grants, such as, prediction or future values and possible commercial application of research results. "Expected impact" is one of the three criteria that can be crucial in making the decision to award the grant evaluated by independent experts. In a situation when the national R\&D budgets are limited, EU funds and programs are also insufficient to support all good projects. In assessing the quality of the project one that can demonstrate impact on technology, society and the economy will have a greater chance of funding. In a survey conducted on 2,500 research projects funded through the three European framework programs in the period from 1998 to 2010 , a request for the industrial and socio-economic application proved to be a key factor in assessing the quality of funded projects (Rodriguez et al. 2013).

At the institutional level for successful participation in EU programs and funds it is necessary to establish standards of professional management of universities and research institutions (Herlitschka et al. 2008). One of the tools for achieving a more efficient and transparent financial management at the academic institutions is the "full costing" method which was introduced by the European Commission in the $\mathrm{FP}_{7}$, as a possibility of budgeting and reimbursing the real cost of research in $R \& D$ projects. The use of full costing method assumes the existence of organizational and IT solutions implemented at the institution that carries out research projects. But this is not often the case in European universities, so the application of full costing model is not carried out to the extent which the European Commission expects. The expectations were based primarily on positive examples of participation of large and medium-sized companies in R\&D projects, which are usually using calculations based on real costs of their operations. The only example of application of a full costing method as a model of sustainable funding in the academic community is TRAC and the UK ("Transparent Approach and Costing").

At a time of budgetary restrictions and financial crisis, for the institutions and members of the European Union it is not easy to meet the requirements of co-financing and additionally that characterize the EU programs and funds. Following problem is term of payments of funds, where payments are sometimes extended on 
for many years causing liquidity and solvency problems for beneficiaries. Nevertheless, analysis of the effectiveness of EU funds in the context of cohesion policy, demonstrate the potential long-term benefits in the less developed regions of Europe. Also, the terms of co-financing and additionally do not have a negative impact on the GDP, while revenues generated by effective investments from EU funds greatly outweigh the expenditure incurred through initial costs of participation (Varga et al. 2010).

\section{RELATIONSHIP BETWEEN EU KNOWLEDE'S TRIANGLE AND EU FUNDING}

Unlike the last century mostly characterized by the individual research, science at the beginning of the 21st century shifts towards research teams and networks. Particular science disciplines are orientated towards research areas, in partnership of the scientific and business communities. Knowledge is seen in the triangle of education, research and innovation that characterize open innovation, strong flow of knowledge, introduction of research results and innovative practices in education, strengthen partnerships and intellectual property management. In order to achieve this, we need a research and educational space that allows and encourages intellectual interaction and business environment that encourages and accepts the "new". The aim should be to investigate with an impact - scientific, economic, cultural and social, which is wider than research with impact factor.

In the aftermath of the economic crisis and to meet the challenges of globalization, there has been a general increase in demand for universities to actively participate in national and regional development processes. The traditional role of higher education institutions is to create knowledge and develop human capital through education and research. For many years now, a discussion about the active role of universities in transfer of knowledge and technology has been going on, as the "third mission" of universities, which is reflected in a direct contribution to the economy and society. Access to relevant competence has traditionally been an important issue for national and regional stakeholders. 30 years back, there have been different concepts which argued the thesis about socially acceptable role of universities as Triple Helix concept that includes strengthening of institutional relations between academia, business community and governmental agencies and bodies. Then the concept of "engaged university", specially developed in Nordic countries, which implies a developed third roll of university i.e. active social involvement, and illustrates the increasingly strategic and conscious role of higher education in regional development. Knowledge Triangle concept involves innovation, as a key element that defines today's modern society that based its development on knowledge (knowledge-based societies). All these elements form the backbone of the national innovation system, which may differ largely in defining stakeholders with a lead- 
ing role in this system. In the "Triangle" model state has a major role in initiating innovation processes, as compared to other approaches to national innovation systems, which focus either on companies and their need for new knowledge and technologies (Etzkowitz et al. 2010). Could, and should, the academic community meet the expectations of the society in which it operates in a way that actively contributes to economic development, not only through education and research? It is a known fact that without qualitative research, there is no quality and relevant education. To what extent can you "direct" and limit time and the duration of the course of basic research to the possible application in the economy and society? Maybe this will remain an open question and the state. This trend is in literature described as "endless transition" model (Etzkowitz et al. 1998) in which the academic community carries out curiosity driven research (endless frontier) which may in the long run result in certain practical applications. Nowadays it is replaced with "endless transition" model that is most often driven by the state with different kind of "knowledge transfer" processes attempting to determine the direction and the expected outcome of basic research.

The contribution of science and new scientific disciplines to technological development and progress of our society is unquestionable. The potential of scientific knowledge has become a key factor of regional, national and international competitiveness. Regions with less developed research facilities are coming to understand the importance of applying science ideas and methods to strengthen local resources as the basis for future economic and social development (Leydesdorff 2000).

This concept is the basis of new strategy for strengthening the innovation potential in the European Union and it is called Smart Specialization Strategy (S3). $\mathrm{S} 3$ is a strategic approach to economic development through targeted support to research and innovation. It can be understood as a plan for the economic transformation of all EU regions based on research and innovation. The methodological approach entails, on the one hand, a serious analysis of local strengths and weaknesses in innovation performance, and identification of areas (sectors) where there are indications of innovative potential that could be strengthen by investments from European financial instruments (ESI - European Structural and Investment Funds, EIT / KICs - European Institute of Innovation and Technology / Knowledge and Innovation Communities, PPP - Public-private Partnership ...). The ideal approach in financing all stages of the innovation chain began with using funds from Horizon2020 programs where excellent science, future and emerging technologies, demonstration and pilot projects in the pre-commercial phase are financed. The results of these projects find their way to the market with the help of funds from ESI funds through procurement of scientific equipment and the construction of innovation infrastructure. It is a very complex process that not only includes a large number of stakeholders (scientific research institutions, universities, higher education institutions, SMEs, large companies, technology centers, 
development and innovation agencies etc.), but implies a very effective coordination of two very complex programs with different implementing rules. Will it achieve the desired synergies in the use of the possibilities of both programs and what will the effects be? It will be interesting to investigate it at the end of the first half of the current financial perspective 2014-2020. It is usually a time when the European Commission and its analytical services conduct first analyses of the effects of implementing financial instruments and achievement indicators set out in the strategic documents.

In this context the effects of Smart Specialization strategy for Croatia will also be observed. The strategy is finally adopted by Croatian Government in April this year, although we are already at the end of the third year of the current financial perspective and strategy is a prerequisite for the use of ESI funds for thematic objective 1 (Strengthening research, technological development and innovation) and thematic objective 2 (Enhancing access to, and use and quality of, information and communication technologies) of Operational Programme Competitiveness and Cohesion 2014-2020. Indication of expected positive effects, regardless of the delay in the publication of the strategy and the relevant calls for proposals, is reflected in the fact that the national specialization areas in the Smart Specialization Strategy are chosen through the participation in the Seventh Framework Programme $\left(\mathrm{FP}_{7}\right)$ for the period 2007 to 2013 .

Table 1.: Specialization areas chosen in the smart specialization strategy of Croatia

\begin{tabular}{|c|c|c|c|}
\hline $\begin{array}{c}\text { Description } \\
\text { of chosen } \\
\text { specialization area }\end{array}$ & Identified capability & $\begin{array}{c}\text { Identified target } \\
\text { market }\end{array}$ & $\begin{array}{c}\text { EU priority } \\
\text { connected to }\end{array}$ \\
\hline $\begin{array}{l}\text { Health and quality } \\
\text { of life }\end{array}$ & $\begin{array}{r}\text { Human health \& social } \\
\text { work activities }\end{array}$ & $\begin{array}{r}\text { Human health \& social } \\
\text { work activities }\end{array}$ & $\begin{array}{r}\text { Public health \& } \\
\text { security }\end{array}$ \\
\hline Bio-economy & $\begin{array}{r}\text { Manufacturing } \\
\text { \& industry } \\
\text {-Biotechnology }\end{array}$ & $\begin{array}{r}\text { Manufacturing } \\
\text { \& industry - } \\
\text { Biotechnology }\end{array}$ & $\begin{array}{r}\text { KETs - Industrial } \\
\text { biotechnology }\end{array}$ \\
\hline Security & $\begin{array}{l}\text { Public administration, } \\
\text { security \& defense }\end{array}$ & $\begin{array}{l}\text { Public administration, } \\
\text { security \& defense }\end{array}$ & $\begin{array}{r}\text { Public health \& } \\
\text { security }\end{array}$ \\
\hline $\begin{array}{l}\text { Energy and sustainable } \\
\text { environment }\end{array}$ & $\begin{array}{r}\text { Energy production \& } \\
\text { distribution - Power } \\
\text { generation/renewable } \\
\text { sources }\end{array}$ & $\begin{array}{r}\text { Energy production \& } \\
\text { distribution - Energy } \\
\text { distribution }\end{array}$ & $\begin{array}{r}\text { Sustainable innovation } \\
\text { - Sustainable energy \& } \\
\text { renewables }\end{array}$ \\
\hline Transport and mobility & $\begin{array}{r}\text { Transporting \& storage } \\
\text { - Water transport \& } \\
\text { related services }\end{array}$ & Transporting \& storage & $\begin{array}{r}\text { Sustainable innovation } \\
\text { - Smart green \& } \\
\text { integrated transport } \\
\text { systems }\end{array}$ \\
\hline Agro-food & $\begin{array}{r}\text { Agriculture, forestry \& } \\
\text { fishing }\end{array}$ & $\begin{array}{r}\text { Manufacturing \& } \\
\text { industry - Food, } \\
\text { beverage \& tobacco } \\
\text { products }\end{array}$ & $\begin{array}{r}\text { Sustainable innovation } \\
\text { - Sustainable } \\
\text { agriculture }\end{array}$ \\
\hline
\end{tabular}

Source: S3 web platform http://s3platform.jrc.ec.europa.eu/eye-ris3 
This table shows the specialization areas chosen by Croatia in the design of smart specialization strategy, the regional capability for the priority, the target market that will be addressed and the EU priority to which this specialization area connects. $\mathrm{Ca}-$ pability and market categories are based on NACE sectoral codes.

With the criterion of scientific excellence, that have the teams of Croatian researchers from universities and research institutes proven with successful participation in the very competitive $\mathrm{FP}_{7}$ program, the choice of areas of specialization influenced the number of technology-oriented small and medium enterprises in Croatia that successfully participated in the $\mathrm{FP}_{7}$ program. The table below shows the number of Croatian SMEs participating in $\mathrm{FP}_{7}$ program and area of their research, or so called $\mathrm{FP}_{7}$ thematic priority. These are companies for which innovation potential in the chosen field of national specialization is estimated ( $\mathrm{N}$ - National smart specialization area chosen).

Figure 1.: Number of SMEs in $\mathrm{FP}_{7}$ research themes - Croatia

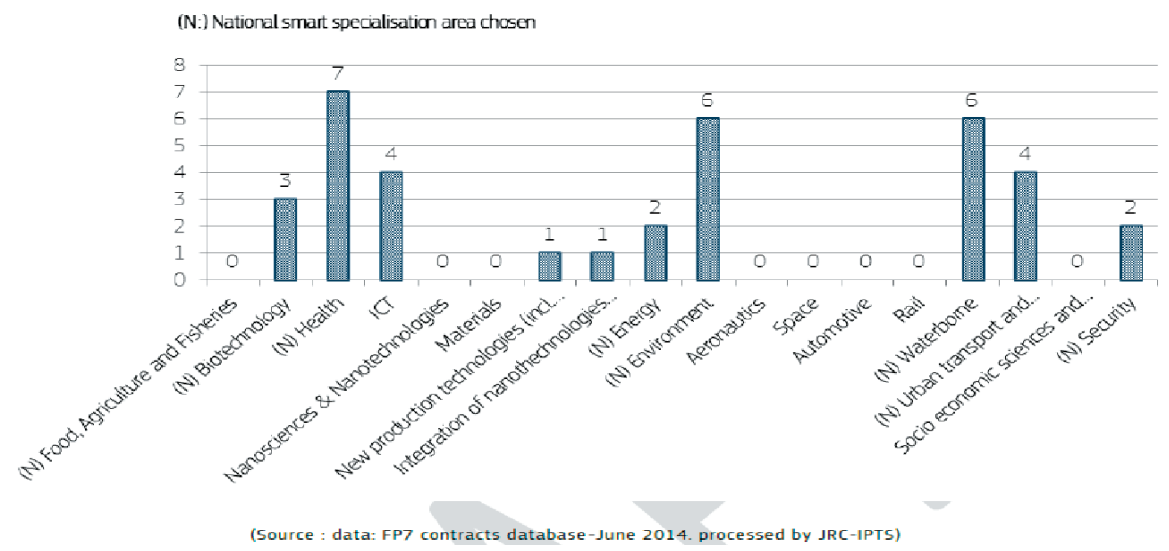

Source: $\mathrm{FP}_{7}$ contracts database - June 2014., processed by JRC-IPTS

\section{CONCLUSION}

This paper has presented, to a certain extent, the impact of external public funding for research in Croatia to the country's research capacity. Qualitative interviews with grant recipients from the Ruder Boskovic Institute provided evidences on positive effects of EU grants in terms of research career, enhanced interaction and knowledge transfer to business community, improved research management competences and possibilities for collaboration with internationally recognized excellent research teams. Similar results from studies carried out in other countries indicates the importance of intangible achievements of research grants, which are becoming more and more relevant in the context of public policies (networking, cooperation, 
strategic planning, knowledge management). The use of EU funds is an extremely complex process which requires a change of approach to the use of public funds and the introduction of the principle of transparency of procedures for all stakeholders in the process, equal access to information and sound financial management. Furthermore, a necessary prerequisite for the use of EU funds is the existence of strategic development plans with identified thematic objectives and investments priorities, instruments for their implementation and measurable result indicators. Unlike Europe, which has identified its strategic priorities and investment areas for future development and consolidate all into one comprehensive document: Europe 2020, in Croatia we have 14, sectoral and horizontal strategies, but there is no national strategy for development. Weaknesses of the Croatian scientific system and absence of will to support excellent research through competitive funding present real threats to successful participation of Croatian researchers in the European framework programs and other external research funding programs. Limited administrative capacities is another important issue that affects successful absorption of EU funds. Therefore, an appropriate instrument should be designed and introduced by science policy officials for building knowledge and institutional capacity to support Croatian researchers to compete in European programs equivalent to their colleagues in the old member states.

Despite the well-known constraints of EU funding policies, especially affecting less developed EU member states (low success rates, co-financing, additionally, complex administrative and financial management), analysis of efficiency of EU funds especially in the context of cohesive politics, show potential of long term benefits in less developed European regions. These regions have less developed research capacities that result in reduced innovation potential. To address these issues European Commission introduced the new concept of applying science ideas and methods to strengthen local comparative advantages and mobilize innovation potential: Smart Specialization. The excellence of Croatian research teams from academic and business communities proved by their successful participation in the $\mathrm{FP}_{7}$ program is a key indicator of the research and innovation potential which will affect the success of implementation of Smart Specialization Strategy in Croatia in the period 20142020.

It would be interesting to investigate the effects of implementing European financial instruments like ESI funds and achievement of indicators set out in the strategic national programs supporting research, development and innovation, in order to provide valuable input for policy makers in Croatia in terms of effective management of overall portfolio of funds available. 


\section{REFERENCES}

Auranen, O. and Nieminen, M. University research funding and publication performance - An international comparison. Research Policy, 39 (6), 2010: 822-834.

Bloch, C., Graversen, E. and Pedersen, H. Competitive Research Grants and Their Impact on Career Performance. Minerva, 52(1), 2014: 77-96

Donovan, C. State of the art in assessing research impact: introduction to a special issue. Research Evaluation, 20(3), 2011: 175-179

Etzkowitz, H., and Leydesdorff, L. The endless transition: A "triple helix" of university-industrygovernment relations. Minerva, 36(3), 1998: 203-208

Etzkowitz, H. and Leydesdorff, L. The dynamics of innovation: from National Systems and "Mode 2" to a Triple Helix of university-industry-government relations. Research Policy, 29(2), 2000: 109-123

Etzkowitz, H., and Ranga, M. A Triple Helix System for Knowledge-based Regional Development: From "Spheres" to "Spaces". Theme paper. Retrieved 16 jun., 2010

European Commission. Diversified Funding streams for University-based research: Impact of external project-based research funding on financial management in universities. Directorate-General for Research. (2008). Available from: http://ec.europa.eu/invest-in-research/pdf/download_en/egexternal_research_funding_final_repor_with_cover.pdf

European Commission. Synergies between $\mathrm{FP}_{7}$, the CIP and the Cohesion Policy Funds. Final report of the Expert Group. Directorate-General for Research and Innovation. Available from: http://bookshop.europa. eu/en/synergies-between-fp7-the-cip-and-the-cohesion-policy-funds-pbKI3211822/, 2011

European Commission. Enabling synergies between European Structural and Investments Funds, Horizon 2020 and other research, innovation and competitiveness-related Union programmes. Guidance for policy-makers and implementing bodies. Directorate-General for Regional and Urban Policy. Available from: http://ec.europa.eu/regional_policy/sources/docgener/guides/synergy/synergies_ en.pdf , 2014

Eurostat Press Office. R\&D expenditure just over 2\% of GDP in the EU28 in 2013. Eurostat News Release. Available from: http://ec.europa.eu/eurostat/documents/2995521/6492099/9-17112014-BP-EN.PDF, November 2014

Fowler, N., Lindahl, M. and Skoeld, D. The projectification of university research. Int J Managing Projects in Bus, 8(1), 2015: 9-32

Ginevicius, R. and Bruzge-, L. Evaluation of the Effect of State Subsidies on Business. Business, Management and Education, $11(1), 2013: 50^{-}-76$

Geuna, A. and Martin, B. University Research Evaluation and Funding: An International Comparison. Minerva, 41 (4), 2003: 277-304

Hasan, A., Cappon, P., Meissner, W., Metcalf, H. and Thornhill, D. OECD Reviews of Tertiary Education. Organization for Economic Co-operation and Development, 2008

Institute for the Development of Education. Project ACCESS - Towards Equitable and Transparent Access to Higher Education in Croatia. Zagreb. Available from: http://www.tempus-access.info/english/ policy-guidelines/339/, 2013

Larsen, P. and von Ins, M. The rate of growth in scientific publication and the decline in coverage provided by Science Citation Index. Scientometrics, 84,(3), 2010: 575-603 
Langfeldt, L., Bloch, C. and Sivertsen, G. Options and limitations in measuring the impact of research grants - evidence from Denmark and Norway. Research Evaluation, 24.(3), 2015: 256-270

Matković, H. and Novak, I. Croatia's participation in the Seventh Framework Programme: A Moderate Success?, Business Systems Research, 4.(2), 2013

McCann, P. and Ortega-Argiles, R. Transforming European regional policy: a results-driven agenda and smart specialization. Oxford Review of Economic Policy, 29(2), 2013: 4.05-4.31

Melin, G. and Danell, R. The top eight percent: development of approved and rejected applicants for a prestigious grant in Sweden. Science and Public Policy, 33(10), 2006: 702-712

Ministry of Science, Education and Sports. Action Plan for the Mobility of Researchers, Republic of Croatia, Available from: http://public.mzos.hr/Default.aspx?sec=3272, 2010

Ministry of Science, Education and Sports, Akcijski plan podizanja apsorpcijskog kapaciteta Republike Hrvatske za sudjelovanje u Okvirnim programima za istraživanje Europske unije 2013. - 2015, Republic of Croatia, Available from: http://public.mzos.hr/Default.aspx? sec=3272, 2013

Ministry of Science, Education and Sports, Croatian Research and Innovation Infrastructures Roadmap, Republic of Croatia, Available from: http://public.mzos.hr/Default.aspx?sec=3272, 2014

Muldur, U. A new deal for an effective European research policy. Dordrecht: Springer, 2007

Pavitt, K. The inevitable limits of EU R\&D funding. Research Policy, 27 (6), 1998: 559-568

Rivera, L. and Reid, A. Participation of South-East European countries in the competitive funding programmes for research in the European Commission. Report to UNESCO-BRESCE. Brussels. Technopolis Group, 2010

Rodriguez, H., Fisher, E. and Schuurbiers, D. Integrating science and society in European Framework Programmes: Trends in project-level solicitations. Research Policy, 42(5), 2013: 1126-1137

Salter, A. and Martin, B. The economic benefits of publicly funded basic research: a critical review. Research Policy, 30(3), 2001: 509-532

Smiths, R.J. Horizon 2020 low success rates a "very sad story". Science/Business. Published: 2015

Varga, J. and In't Veld, J. The Potential Impact of EU Cohesion Policy Spending in the 2007-13

Programming period: A Model-Based Analysis, Economic Papers No. 422., 2010

Whitley, R. and Gloeser, J. Organizational transformation and scientific change. Bingley, U.K.: Emerald, 2014 